\title{
Unfamiliar Acts of Citizenship: Enacting Citizenship in Vernacular Music and Language from the Space of Marginalised Intergenerational Migration DOI:
}

10.1080/13621025.2015.1132566

\section{Document Version \\ Accepted author manuscript}

Link to publication record in Manchester Research Explorer

Citation for published version (APA):

Ní Mhurchú, A. (2016). Unfamiliar Acts of Citizenship: Enacting Citizenship in Vernacular Music and Language from the Space of Marginalised Intergenerational Migration. Citizenship Studies.

https://doi.org/10.1080/13621025.2015.1132566

Published in:

Citizenship Studies

\section{Citing this paper}

Please note that where the full-text provided on Manchester Research Explorer is the Author Accepted Manuscript or Proof version this may differ from the final Published version. If citing, it is advised that you check and use the publisher's definitive version.

\section{General rights}

Copyright and moral rights for the publications made accessible in the Research Explorer are retained by the authors and/or other copyright owners and it is a condition of accessing publications that users recognise and abide by the legal requirements associated with these rights.

\section{Takedown policy}

If you believe that this document breaches copyright please refer to the University of Manchester's Takedown Procedures [http://man.ac.uk/04Y6Bo] or contact uml.scholarlycommunications@manchester.ac.uk providing relevant details, so we can investigate your claim.

\section{OPEN ACCESS}




\title{
Unfamiliar acts of Citizenship: Enacting Citizenship from the Space of Marginalised Intergenerational Migration
}

\author{
Aoileann Ní Mhurchú ${ }^{1}$, School of Social Sciences, University of Manchester
}

Published in Citizenship Studies Vol.20 2016, Issue 2, Special Issue entitled '(En)gendering the Political: Citizenship from Marginal Spaces': pp156-172

\begin{abstract}
Conceptualizing citizenship as an act rather than a status enables us to rethink the familiarity of both 'who' can be a citizen and of the 'type' of practices that can be understood as citizenship. This paper explores the liminal site from which intergenerational migrant youth resist the taken-for-granted space of citizenship through a turn towards vernacular music and language, and doing so focuses on unfamiliar acts of citizenship per se. It considers how citizenship is resisted here through the unfamiliar act of turning away from either identifying or, failing/refusing to identify with the nation-state. It explores the effect of this move in challenging narrow national linguistic and ethnic ideologies through the development of non-standard language practice and cross-cutting musical styles. It argues that citizenship is enacted in this move by creating a space in vernacular music and language for expressions of hybrid political identity and belonging.
\end{abstract}

Key words: acts of citizenship, intergenerational, language, migration, music, resistance, unfamiliar

Acknowledgements: I would like to thank Reiko Shindo and the two anonymous reviewers for detailed and constructive engagement with earlier drafts of this paper. A draft of this paper was presented at the European Consortium for Political Research (ECPR) in Glasgow in September 2014 and at the University of Manchester Critical Global Politics Research Seminar series in December 2014 where it benefited from questions and comments from audience members and fellow panelists.

\footnotetext{
${ }^{1}$ aoileann.nimhurchu@manchester.ac.uk
} 
An act does not exist as a now within a series of nows. Rather, acts are continually becoming and arriving in various forms. Morrison 2008, p.223

[T] he struggle at the heart of migrant politics is a battle not only over what kinds of protest and protestors can be seen and heard (as politics) but also more fundamentally what kinds of resistance are imagined as possible. Tyler 2013 p.213

\section{Introduction}

The notion of citizenship as an act (a practice) rather than a status (Isin and Neilson 2008) has brought about a huge challenge to the dominant idea of 'active citizenship' and thereby to how we understand what it is to be political in the social sciences. Whereas the idea of active citizenship emphasizes familiar ways of being political tied up in ideas of belonging as a right and associated duties, the notion of citizenship as an act has enabled explorations into unfamiliar and disruptive possibilities of being political by focusing on how rights-claims are constantly remade in the name of belonging (Isin and Nyers 2014; Isin and Saward 2014) This paper contributes to this latter engagement with disruptive and unfamiliar possibilities of being political, looking specifically at migrant youth and the subtlety of political enactment undertaken by them.

Conceptualizing citizenship as an act (Isin and Neilson 2008) links citizenship to the process of claiming and performing rights to belong; it thus enables us to rethink 'who' can be a citizen beyond the already-existing rights-bearing liberal subject. It also enables us to rethink 'what type' of practices can be understood as citizenship, beyond the repetition of practices that merely affirm socio-historical patterns, but as actions which also disrupt, and rupture these. In the context of migration studies, particular attention has been paid thus far to the former - namely to how unfamiliar actors such as undocumented adult migrants undertake familiar practices of resistance such as marching, withdrawing labour, voicing descent, strikes, protests, raising/waving of flags and sit ins - thereby interrupting existing socio-historical patterns. These are actions whose target is the state and its institutions or other existing polities such as the European Union, which have demanded a range of issues, from redistribution to more formal and substantive rights (e.g. Ashutosh 2013; McNevin 2011; Nyers 2008). Such work has challenged the figure of 'who' is understood to be able to claim citizenship.

Increasingly, there is an emphasis on thinking about practices of citizenship linked to less immediately perceptibly political acts in order to further recognise the multiple and contested nature of political subjectivity (Morrison 2008; Neveu 2014). This paper contributes to and extends 
these inquiries, and thereby our understanding of the unfamiliar disruptive possibilities of being political more generally, by exploring the liminal site from which intergenerational urban migrant youth resist the taken for granted space of citizenship. It looks at how they do so by turning away from identifying or failing/refusing to identify with the nation-state (without grounding belonging at the city or international level either) towards vernacular music and language. It explores the effect of this move in challenging standardised national language and ethnicity ideologies through the development by youth of non-standard regional language practices and cross-cutting musical styles which mix together and undermine mono linguistic and ethnic affiliations. Doing so this paper contributes to our understanding of 'everyday resistance' as an indirect practice linked to subtle destabilisations (which draw upon rather than oppose) dominant national spaces of political identity and belonging. This complements work thus far which has captured more direct challenges (clearly articulated dissatisfaction) to the national space of political identity in migrant activism.

This paper firstly looks how conceptualizing citizenship as an act foregrounds social struggle (what people do rather than who they are). This allows us not only to think about citizenship as a direct challenge to an existing polity, such as the nation-state, the city, or an international body and a re-configuration of this - but also to imagine citizenship beyond (working through but not limited to) these existing polities. It subsequently explores how marginalised intergenerational migrant youth's experiences at the level of the everyday invoke important questions about belonging in terms of vernacular music and language. I consider the political effect of this turn towards vernacular music and language: namely that it indirectly challenges a narrow national linguistic space which has tended to be based around normally one, or only several prioritised languages ('monoglot standardization' (Blackledge 2004 p.72)) and ethnicity ideology (the symbolic linking together of ethnicity and culture). I posit that by taking this political effect into account, this turn towards vernacular music and language can be read as an act of citizenship given that it involves creative processes of drawing on and mixing up sanctioned 'national' and 'non-national' resources by young people, which produce different understandings of 'who' they are/can be beyond the dominant national space of political identity and belonging. The paper considers in the third part how practices of engagement in vernacular music and language can be understood not only as disruptive acts into hegemonic understandings of citizenship, but as enacting a form of hybrid citizenship. 


\section{Broadening the Concept of Citizenship}

Traditionally, citizenship studies has explored citizenship as a realm of ordered linear, formal and legal status which the individual negotiates, where the importance of enabling progressive rights and duties to reduce inclusive/exclusive hierarchies across citizenship is stressed (Ní Mhurchú 2014a). In contrast, by focusing on ideas of rupture in existing socio-historical patterns about 'who' can be a citizen and 'what practices' can be associated with citizenship, the acts of citizenship literature has brought to the fore ideas of complex and irregular belonging and identification; and thereby unfamiliar ways of being political (Isin and Neilson 2008; McNevin 2011). It has drawn attention to ambiguous, complex and irregular political agency which exceed the traditional citizen/second-class citizen dualism. It emphasises instead a messy unordered collective of neurotic citizens, irregular citizens, abject citizens, illegal citizens, and ambiguous citizens (Isin and Nyers 2014a and 2014b; Ní Mhurchú 2014b). These are citizens who are caught between many different polities - polities of various levels of formal authority including the European Union, the United Nations, the city, as well as various covenants, agreements and charters that constitute these polities. Within migration studies while unfamiliar 'acts' do emerge at present, their unfamiliarity is often based on contradictions across familiar acts rather than unfamiliar acts per se. For example, the acts themselves which are pointed to include demands made by irregular migrants for recognition through demonstrations, occupations and marches, and are familiar acts in discussions about citizenship traditionally. The way in which politicised nonstatus migrants make these demands, for example, both in the national language and in the presence of foreign-language placards, music, dress and performances is unfamiliar (Butler and Spivak 2007; McNevin 2011) in its contradictory nature mostly. It is the unfamiliarity of familiar acts which is disorienting in this existing literature rather than unfamiliar acts themselves therefore.

As Morrison (2008) notes in the opening quote, the notion of citizenship as an act which is both disruptive of the status quo and in itself ('continually becoming and arriving in various forms') emphasises the idea of unfamiliar acts of citizenship per se. It is by following this line of inquiry that this paper extends analysis in the field of critical citizenship studies. It stretches our understanding of the nature of citizenship as an act in keeping with the multiplicity of political agency within the context of migration (Nyers and Rygiel 2012). For, understanding citizenship as a process of 'negotiating different situations and identities, and articulating ourselves as distinct from, yet similar to, others in our everyday lives' (Isin and Nyers 2014a, p.4) as critical citizenship studies does, emphasises (and opens up) the question of social struggle itself through which a sense of rights and duties vis-à-vis a 'polity' can be established. It indicates that this can involve foregrounding the 
process through which people engage with each other on a day-to-day basis to articulate themselves as part of a polity, as well as by enacting a challenge to existing polities.

To build on these existing insights in critical citizenship studies I turn to a group which tends to be the focus of much debate about the intersection of migration and citizenship but whose possibility as political subjects very rarely inform such discussions: these are marginalised intergenerational migrant youth. This group are only implicitly linked to this intersection through the actions, views and experiences of migrant adults, in particular migrant mothers (Lentin 2003; Tyler 2013). Even when focused upon, it is often only as people who have been failed by the existing liberal democratic regime(s) rather than people who challenge this in a substantive way (Bhabha 2009; Cohen 2005). ${ }^{2}$ This is in contrast to a growing literature within youth studies which has in recent decades emphasised the specificities of young people's political agency in all its (un)familiarity, and in particular of migrant youth (e.g. Boehm et al 2011; Hoerder et al 2005; Kallio and Häkli 2013; Maira and Soep 2005; Nortier and Svendsen 2015). This paper, as such, does not turn away from thinking about (ir)regular migrants as an important group in the context of how we understand 'acts of citizenship'; but it considers how a nuanced understanding of the different generational experiences (as social locations) of migrant groups, helps us think further about the unfamiliar nature of such acts.

\section{Marginalised Intergenerational Migrant Youth: Turning away from Existing Polities}

The term intergenerational migrant youth refers to those who migrated at a very young age (below 12) often called the ' 1.5 generation' and those born in a country which their parent(s) or grandparent(s) migrated to - often called 'second generation migrants'. Portes and Zhou (1993) called this group 'The New Second Generation' and distinguish their experience of adaptation from those of adult migrants. I focus specifically on the lives of marginalised intergenerational migrant youth - that is, intergenerational migrant youth who experience discrimination due to their own precarious status, that of their parents/immediate family members or that of their family's historical relationship with the state (and often a combination of these). By 'youthful agent' I draw on Kallio and Häkli's definition (2013, p.7) of someone 'who occupies a minor position in her/his specific geoeconomic and socio-cultural community and society'.

Intergenerational migrant youth are often linked to both citizenship and migration, however normally at different times, for different purposes and without much discussion as to what the

\footnotetext{
${ }^{2}$ An exception is literature on the undocumented youth known as DREAMERS and their various acts of civil disobedience including 'coming out of the shadows' rallies, sit-ins, mock(ing) graduations and hunger strikes. These acts are however focused on acquiring formal citizenship and directed at the federal and state level unlike the indirect acts focused on in this paper.
} 
implications of linking them to both citizenship and migration might be for how we understand 'citizenship' (Ní Mhurchú 2014a). It is as people caught between these categories - rather than falling into one category or the other and/or straddling them equally - that I focus on them here. I argue that the actions of intergenerational migrant youth force us to rethink how we have come to understand the politics of citizenship because their actions are not directed at overtly challenging the boundaries of existing polities such as the nation or state, city, or international polity but involve turning away from these towards music and language. Such actions can be understood I argue in a way that avoids the blackmail of needing to define them as either political or non-political if we theorise them as 'a mode of political presence' and think about how some modes of political presence first appear as political absence (Kallio 2012 p.294).

One of the difficulties with focusing on youth when thinking and talking about citizenship is that young people find themselves residing within a 'generational milieu' (Hoerder et al 2005, p.15) where past, present and future meet processes of change and rupture (Boham et al 2011). As inhabitants of this generational milieu, young people are at the epicentre of where identities, power relations and social change engage and interact; however because most societies naturalise socialisation by adults of youth, and elevate the culture of adults during working life to the position of 'the' culture, youth are rendered invisible often from questions about the choices, challenges and changes involved in cultural negotiation and transfer (ibid). In effect, the power relations through which young people resist and navigate their everyday lives - which involve negotiating relations of peer cultural communities, following and engaging in familial and local norms, forging and protecting bonds in their personal relationships - take place at the intersection of various temporal and spatial senses of place, locality, globality, culture, symbolic significance, futurity and possibility which render them less visible. Youth have many possible ways of grounding this sense of self which they must negotiate and voice, which can be less visible given their messy nature. Yet, it is precisely often at this intersection and atypical voice that they make present their political subjectivities.

For example, in their study of 1.5 generation migrant youth growing up in Ireland, Ní Laoire et al (2011) look at how young people articulate their sense of political identity and belonging in ways which indirectly confound categories such as 'Irish' and 'migrant' as useful hierarchies for understanding national processes of othering. Youth did so through practices and relationships linked to combinations of music, fashion, school, sport, and language across national and international as well as regional and local spaces. In other words, some youth did not simply reject hierarchies of sameness and difference which underpin national processes of othering - thus acknowledging them in such a rejection - but by turning away from them. Their actions lacked immediate clarity of message. 
Most notably, some young people when faced with discourses of exclusion - which included forms of othering ranging from more benign to overtly racist claims about their lack of 'Irishness' did not seek to challenge these and demonstrate alternative ways in which they were integrated 'Irish' citizen nationals at the level of the state, the city or the European Union (for example by emphasising their links to Ireland, such as being born there, coming from countries with colonial links to Ireland, or having families who contributed financially to Ireland (See McNevin 2011 on how the Sans Papiers do this)). Rather they began to associate exclusion with the dominant national identity; in this case 'being Irish' was seen as 'a way of being in the world firmly rooted in the local and indifferent to other ways of doing, being and perceiving' (Ní Laoire et al 2009, p.74). Some migrant youth opted as a result to turn away from this: even from the process of identifying the limitations of the national polity in favour of other types of international or sub-national polity. They turned instead towards, most notably, music and language which are often associated with subversive subculture within a given society (Hebdige 1979). ${ }^{3}$

The groups looked at in this study by Ní Laoire et al (2011) for whom this was a feature included youth from African backgrounds and Latin American youth living in Ireland, many growing up in the asylum system. What became important for such youth was developing belonging via globalised culture, including through music (such as rap) and languages (in particular code-switching) among like-minded peers in response to experiences of marginalisation and isolation (ibid). One way of seeing these, I argue, is as manifestations of attempts by some intergenerational migrant youth to develop a hybrid self and a polity based on such hybridity in the face of exclusion from existing national polities which they do not fall into: to create "the proverbial 'room of one's own"" (Mushaben 2008, p.508). What we can think about is the possibility of 'artistic phrasing' in music and language by youth to 'reshape terms and meanings in the interest of self-distinction' (FernándezKelly \& Konczal 2007, p.1165) in response to marginalisation in society associated with national culture. I posit such acts as political by understanding 'everyday resistance' (being political) as a practice and thus not reducible to intentions but as that which can be explored through its effects across society (Foucault 1978; Vinthagen and Johansson 2013). This allows us to link 'being political' to even subtle challenges to dominant power relations (with all the messiness this entails) rather than merely dialogue whereby a clear message is conveyed through intentions. Specifically, I argue that the turn to vernacular music and language described above and explored further below should be seen as a political act as it involves a refashioning of the self by youth by destabilizing the

\footnotetext{
${ }^{3}$ This is not to ignore how music, language and fashion can be used also to reinforce cultural hierarchies in keeping with active citizenship (practices that re-entrench existing socio-historical practices) rather than acts of citizenship (acts that disrupt these). Ní Laoire et al (2011) also, for example, explore how some youth drew on language, fashion and music and sport in the form of traditional Irish dancing, the Irish Celtic language and Irish Gaelic football or hurling to try to reaffirm their 'Irish' Identity.
} 
dominant narrow national space of political identity and belonging.

To explain, the Irish nationalist project has following independence from the British Empire in the early nineteenth century been deeply cultural, with the Celtic language, music and heritage seen as a bridge to past generations of the imagined Celtic nation (Dowling 1997). Put simply, the Irish nationalist political project is deeply anchored in the idea of two official languages (Gaelic and English), official music (Gaelic music) and Celtic heritage. Despite official adherence to interculturalism in Ireland (based upon ideals of diversity and tolerance), 'interculturalism' is institutionalised under 'integration' which is underpinned clearly by a linguistic hierarchy as well as an ethnic understanding of 'Irishness'. Most notably, the Irish citizenship test requires fluency in either English or Gaelic and in recent decades it has become increasingly difficult for those born in Ireland to automatically acquire Irish citizenship without the necessary Gaelic ethnic background (due to major changes introduced under the 2004 Irish Citizenship Referendum) while it has remained very possible for those born abroad to automatically acquire Irish citizenship through Gaelic ethnic heritage (Mancini and Finlay 2008). Yet, the turn to vernacular music and language engaged in by people in Ireland challenges this national space of belonging by drawing aspects of existing 'national' language and music together with various other music and linguistic influences in particular African American hip hop - in ways which are unsettling and disrupting, not least because they are familiar and unfamiliar at the same time. It allows for creative processes of drawing on and mixing up sanctioned 'national' and 'non-national' resources through which young people can experiment with different understandings of 'who' they are/can be, as I discuss further below. These however remain ungrounded, thus distinguishing them from ideas about 'multiculturalism' which emphasise various groundings of difference.

\section{Language, Music and Resistance}

The relationship between music and resistance has been widely documented, in particular in relation to slave-songs, post-war youth mod and rocker music as well as hip-hop (Keyes 2002; Sullivan 2001). Hip hop itself, in particular has become synonymous with youth subculture and resistance, originating as it did in the US among disadvantaged youth of colour as a medium for bringing attention to the social and political realities in which they were forced to live. Nonetheless, in recent decades, a number of studies have demonstrated new developments around engagement in hip-hop and language use by immigrant youth in diversely populated urban areas (e.g. Hoeder et al 2005). Exposure to multiple cultures and linguistic influences in such spaces, and increased global awareness, have been shown to be developing novel (albeit not unique) practices of language mix and hip-hop due to the specificities of the local-global influences in each given context (Nortier and 
Dorjeijn 2013; Nortier and Svendsen 2015).

Sunaina Maira (2008) for example, has explored the resistant practices against exclusion and discrimination (linked to imperialism, racism, inequality) enabled by Palestinian-American hip-hop affiliated youth in a post 9/11 security-oriented highly diverse urban context. She focuses in particular on the tangibility of descent in the words used in hip hop here. That said, she elsewhere $(2005, p .69)$ points to aspects of 'reframing the basis of citizenship' within such youth practices; in particular the possibility in them of 'a complex set of political affiliations and social boundary crossings' in subtle ways (emphasis added). Others such as Irina Schmitt (2005) and Cutler and Royneland (2015) have drawn a specific link between vernacular music such as hip-hop and vernacular language; in particular pointing to increasing mixtures of local, indigenous and migrant languages which form the base language for hip-hop. This allows us to think about how hip hop not only conveys a message (acts as a medium) to express dissatisfaction with society and point to wrongs but also has become a tool to 'establish solidarity with fellow community members and to strengthen their position in society' (ibid, p.140) by infusing a variety of cultural linguistic and musical influences into hip hop itself in a way that cuts across traditional categories of ethnicity or language use. This work points, as such, to the need to think further about the processes and effects of vernacular music and language: that is, about what is gained by those who engage in them (rather than just what can be expressed verbally through them). This paper builds on such literature by foregrounding the importance of the subtlety of engagement with vernacular music and language: both how the process facilitates creative hybrid refashioning of self, and its indirect impact on undermining dominant ideals of national linguistic and ethnic identity and belonging, which involve drawing on these dominant ideals and mixing them up with others, rather than opposing them.

\section{Verlan and Hip Hop in France}

One of the places where language and music have been linked in various ways to the experiences and actions of marginalised intergenerational migrant youth is in France (Drissel 2009; Durand 2002; Lefkowitz 1992). Pointed to are young people, in particular those from North African families, who grow up in France yet are relegated to the peripheries of French society: both physically by being housed on the outskirts of cities in France's banlieus, and symbolically through their identification as yet another generation of migrants (a 'second generation'). These are people born in France often without being recognised as 'French', yet are not 'migrants' either given that their only tie with their parent's birthplace is frequently simply an occasional visit or vacation. In an attempt to deal with exclusionary discourses - their experiences of falling short of the image of a 'French citizen' given that they are 'caught between the culture of their parents, which they no longer possess, and the 
French culture to which they don't have complete access' (Lefkowitz 1991, p.137) - many have displayed what can be understood as a turn away from the existing national, city or international polity towards music and language in their use of the slang 'Verlan' and rap music.

Verlan is linked to an ancient form of word-play (called Argot) which involves inverting syllables.I It uses French as a base language but draws on vocabulary from across immigrant languages and involves 'creative' modifications across speech and grammatical structure (Nortier and Dorleijn 2013). ${ }^{4}$ Verlan forms a key part of French rap, the second largest rap market in the world. Both rap and Verlan are known for their informal and cross-cultural references. Speaking about Verlan, one woman explains when asked why she uses it (quoted in Doran 2004, p.93) that it is part of an attempt to produce oneself as a subject and as part of a polity: 'because we are looking for ourselves, and we can't find ourselves' in either 'French' or the alternatives of 'non-French' culture, but always as a mixture of both and neither.

The turn to rap and Verlan in France can be seen as political because of the huge role language has played in French nation-building. The French language has historically served as 'the major vehicle for the transmission of the national culture and...revolutionary ideology' (Safran 1992, p793); with the Académie Française set up in 1635 to protect it, and French institutionalised as the sole language of instruction in 1891 . This continues today with the French language seen as the vehicle for national unity in the face of growing diversity (Villard and Yan Sayegh 2013). Any attempts to undermine the centrality of the French language are still understood by the Académie Française as threatening 'French identity', and this is a view echoed by the French Senate which vetoed attempts to recognise regional languages in the French Constitution as recent as 2008 (ibid, p.244). Any ethnic differences furthermore in the French ideal of the Republic are presumed to be subsumable into a 'French' common nationality forcing people to choose between being French or not. As explained by Drissel (2009, p.121), however, 'French hip-hoppers are involved in a complex process of reconfiguring and synthesizing relevant idioms and vernaculars found not only in global hip-hop and their "native" culture but also in their "host" country of France'. The use of language mix and hip hop is thus understood to be both reflecting and influencing the construction of hybridised identities which undermine the spaces of national linguistic homogeneity and ethnic identification: this is the space where a national language is linked to an originary overarching culture (ethnicity) and this is imposed on everyone on the basis of facilitating integration.

Indeed, there has been in recent decades increased emphasis in countries of inward migration in Europe on the need for language homogeneity or a standardised national language (Blackledge 2004). In some countries there is one prioritised national language such as in France

\footnotetext{
${ }^{4}$ The official term of this 'slang-like linguistic style' is a multi-ethnolect (ibid).
} 
(French) or Germany (German); in other countries there is more than one choice such as in Ireland (English or Gaelic) and in Belgium (French or Flemish). However hierarchy and a narrow element of choice is a defining feature here across all despite the reality of large linguistic diversity (ibid; Alexander et al 2007). What is articulated in vernacular music in its form (as I further tease out below) is a refusal of the idea that national identity and belonging can be fit into one space rather than an other space. As one hip hop artist Stromae (whose name is a Verlan inversion of 'Maestro') notes in his song 'Bastard': you are told 'either you are one or the other....Are you Flemish or Wallonian?... Are you white or brown, eh ${ }^{\prime 5}$ Having grown up in a French Belgian suburb with a Flemish Belgian mother and a Rwandan father, Stromae's upbringing mirrors the mixed linguistic and ethnic urban environment of immigrant youth pointed to in existing literature (Nortier and Svendsen 2015). His refrain is that he is neither and never has been: 'neither one nor the other I am; I was and I will remain myself'. ${ }^{6}$

\section{Marginalisation, Irregularity and Hybridity}

In many of the examples above the migrant youth are those who have some form of status in the societies in which they live - this can be by virtue of being born there and acquiring citizenship at birth, by virtue of having a citizen parent, and/or by virtue of being a child and having rights linked to education and welfare as a child regardless of status. For example, in many European countries children regardless of status are entitled to free access to primary and secondary school education as well as health care; as such they possess a form of status - understood as entitlement to rights which their parents do not enjoy, simply by virtue of being under 18 . However at the same time they are people whose status is precarious given their broader family circumstances which include having irregular migrant parent(s) who are asylum seekers, on short term visas, or who cannot be deported for various reasons linked to their connection to a citizen (for example having a child who becomes a citizen) but who are still not entitled to work or to other rights.

This emphasises the differences between how youth and adults experience precarity (irregularity) in their daily lives, thus drawing distinctions between generational experiences on the basis of positionality rather than entrenched cultural identity. This leaves open the possibility of recognising intra-generational experiences in other respects which puts into practice what some work (e.g. Anthias (2009)) stresses is very importance when thinking about migration across generations. Whereas irregular adult migrants may be in danger of immanent deportation and/or find it very difficult to avail of basic services (such as health, employment, education), marginalised intergenerational migrants will often be in school, and able to avail of basic services for free as

\footnotetext{
${ }^{5}$ Sois t'es l'un ou soit t'es l'autre...Flamand our Wallon?... Mais t'es blanc ou bien t'es marron, hein?

${ }^{6} \mathrm{Ni}$ I'un ni l'autre, je suis; j'etais et resterai moi
} 
typical 'citizens' do; as such they experience less explicit forms of exclusion than adults often do, as their exclusion is often defined through their wider family situation rather than linked merely to themselves and their status. Marginality however does not rest only in access to formal status. The example of France demonstrates that intergenerational migrant youth may have formal citizenship and live within families where all members also have formal citizenship but their family's history of migration may have resulted in disenfranchisement which has persisted across generations.

It often makes sense therefore for irregular adult migrants to challenge their explicit exclusion through overt political gestures of outright resistance which are directed at the political authority which excludes them - the state, city, European Union, or convention. For intergenerational migrant youth, however, whose exclusion is implicit as much as explicit, the problem can appear as the authority (polity) itself; as a link between Ireland, France, Europe etc. and exclusion. This is expressed by one youth as follows in a study on use of Verlan: 'I don't like the French system. In France, it's each person for himself' (Doran 2003:114). It is in this context that music and language can be understood to provide a space in which different conceptions of identity and belonging are experimented with, explored and enabled, ultimately challenging a restricted national linguistic space and restricted ethnic cultural affiliation.

Indeed, as intergenerational migrant youth negotiate belonging across a range of spatiotemporal sites - including school, home, peer-groups, music, fashion, etc., - something that unites these claims to belong is how they draw on multiple, often overlapping ideas of belonging which are paradoxical and very rarely straightforward (Ní Laoire et al 2011, p.47). What I want to suggest is that vernacular music and language provides a space to develop such contradictory claims of belonging and being with others who they see as like-minded rather than of a particular nationality or ethnicity etc., albeit not necessarily in a direct, deliberate way. This does not create a distinctive polity, understood as an organised society, akin to a state or a city or a common humanity. But rather a highly fluid space in which belonging, identity and affiliation so integral to the foundations of citizenship, are constantly re-enacted. It is highly fluid because although there are lots of signifiers - of nationality, ethnicity, race, gender etc. - these are not grounded in a particular nation, ethnicity or form of statehood based around one or two languages and ethnicities. This is a space defined by hybridity across languages and ethnicities.

\section{Creative resources for Hybrid Self-expression in Vernacular Street Music and Language}

When looking at intergenerational migrant youth in Ireland and their responses to discourses of marginalisation, Ní Laoire et al's (2011) work shows that the problem identified by youth themselves 
was not just that they didn't fit simply into the categories of 'Irish' and 'non-Irish' or 'African' but that they also didn't fit into the newly hyphenated identities of 'African-Irish' or 'New-Irish' which were opening up. Key issues with fitting into such categories are to do with the number of places intergenerational youth identify as 'home': including their neighbourhood, their city, their parent's country of birth, their own country of birth, and their current place of residence, as well as their multiple linguistic affiliations and broader cultural identifications - which are often contradictory given that not all of these are places which they visit or spend much time in, nor languages which they speak very well, nor cultures which they are necessarily very familiar with (c.f Lee 2002; Yau 2007). What ensues is a negotiation of home and belonging in multiple contexts through simultaneous notions of attachment and detachment to particular places in a way that disrupt(s) 'any simple opposition between roots and routes, or movement and attachment' (Ní Laoire et al 2011, p.48).

As discussed above, unlike many adult migrants who can less problematically act and exist as individuals in the present, youth are situated in their collective and intergenerational relations across times (past present and future) and many spaces (here, there, ancestral home, current home, parents home) many of which (unlike their parents) they will have had little direct access to (Kallio and Häkli 2013 p.11; Ní Laoire et al 2011). Speaking different languages is often a key way in which intergenerational migrant youth perform and embody belonging as a result (Darmody et al 2011; Nortier and Svendsen 2015). The point is that intergenerational youth may be exposed to several languages which they may use at different times and in different places depending on who they are talking to (whether it is their parents, teachers, or friends) and where they are (at home, in school, on the street) (Doran 2003; Ní Laoire et al 2011). Rather than identity being reflected through language or visa-versa, these become mutually constitutive.

The turn to vernacular language, such as slang, and music such as rap, in the multiple fashion that it is being engaged today, within highly diverse urban environments, can thus be seen as a way in which intergenerational migrant youth negotiate the multiplicity of their lives. Vernacular music and language provide a milieu which enables hybridity - inconsistency and overlap - rather than requiring coherency and consistency. We might therefore see them as milieus which enable subversive 'noise' (Hebdige 1979, p.90; Kallio 2012); as sites of disagreement which convey political contestation in their effect of undermining the idea of a single nationally defined culture or language without necessarily positing a coherent alternative or reifying clear cultural difference. Although they don't voice their concerns through existing politically recognisable channels or as forms of direct dissatisfaction, I suggest that youth can be seen to 'noise' (Kallio 2012, p.295) their concerns nonetheless in their use of vernacular language and music by presenting different variants of 
political belonging in Ireland and France which indirectly challenge a a narrow choice of language (French, or Gaelic and English) and a clearly defined ethnicity (French or Arab; African or merely African-Irish.)

As Ní Laoire et al discuss (2011, p.68): 'For some African/Irish young people the appeal of particular fashions, styles or music was that they were globalised - that they weren't [just] "Irish" or "Nigerian" or "Somalian" or "Kenyan". This demonstrates how fluidity is prioritised. These categories are not unimportant to intergenerational migrant youth; on the contrary the point is that many of these categories are very important and significant to how they identify themselves rather than just one or two of them. Through globalised vernacular music and language they can mix these together, however, to allow different presentations of the self which result in a more fluid ongoing (re)mapping of political imaginaries (Drissell 2009; Perry 2008). The idea of 'indirect resistance' as (those acts of resistance which ignore, transcend or move beyond what they are resisting) as a form of everyday resistances thus presents an alternative to the oppositional understanding of 'everyday resistances' which is stressed elsewhere. For example, James Scott $(2014$, p.62) argues that it is 'opposition' which gives everyday resistance meaning; saying '[w]e can't understand British youth culture of mods and rockers without seeing it in contrast to the clerk with the furled umbrella and the bowler hat as the standard bourgeois male Londoner'. The notion of 'indirect resistance' cannot be separated from what is politically at stake in everyday resistances; in the case of vernacular music and language this is the undermining of 'monoglot standardization' (Blackledge 2004 p.72) and ethnicity ideology. However, rather differently from Scott's statement above, the meaning of 'indirect resistance' lies in how it draws upon dominant practices (e.g. dominant linguistic and ethnic markers) and plays with these (by mixing them up with others) in order to undermine them rather than by opposing dominant practices.

The way in which such hybrid (mixed) presentations of the self come together in music can be seen in how French rap for example is a synthesis of influences from around the world including French, African American, North African and African Caribbean expressive culture, and draws on preexisting musical genres from French traditional music, rock, jazz, and gospel. This is furthermore inseparable from the informal language of Verlan which is seen as key to its expressive wordplay and poetic depiction of life in French banlieus (Durand 2002). What is enabled is a type of 'third space' (Bhabha 1994) in which 'a complex, multicultural, working-class identity...[can] be both performed and recognised in a way that they are not within the larger society' (Doran 2004 p.95). One of the things to note therefore is the creative resource in music such as rap and in slang like Verlan. It provides the opportunity to mix the old with the new; to be adapted and changed to fit circumstances. To some extent this can be said about any type of music; however it also depends on 
the extent to which music and language is tied to the vernacular (Rosenthal and Flacks 2012). Music such as rap, blues and jazz for example and 'contact languages' (Nortier and Dorleijn 2013) whose development is as street vernacular (everyday music and language) due to their lack of grammatical and linguistic rigidity can be reworked over and over again in ways that enable them to adapt and incorporate multiple cultural influences (ibid; Rosenthal and Flacks 2012). Here we get away from the idea of fixed cultures simply coming together towards movement, change and disruption; in particular towards young people's agency in (re)forming ideas of political identity and belongings: reforming what it means to identify in France or Ireland via multiple (rather than only one or several narrow) languages and ethnicity (Ní Laoire et al 2011; Perry 2008). For example, the lack of grammatical rigidity enables those engaging in Verlan to draw on and draw together many different influences from Arabic, Creole and African languages as well as Romani and Argot. Its meanings constantly adapt and move within and among these influences where youth combine different grammatical elements of various languages in ways that break rules within these individual languages all the while using French as the base language (Doran 2003; Nortier and Dorleijn 2013). Verlan and rap, as such articulate not only the poverty and disaffection of the banlieu(s) but also the hybrid linguistic, ethnic make-up of the banlieus. Youth deal with contradictions between competing understandings of 'home' by mixing and matching different influences to undermine a dominant national idea of 'home' linked to a particular ethnicity and language.

\section{Re-enacting Citizenship}

Although there is increasingly more written about the multiple and often very diverse forms of adaptation among intergenerational migrant youth, these are reluctantly linked to citizenship per se. Instead, citizenship in such instances is often contrasted (juxtaposed) with hyphenated identities: for example, Mushaben $(2008$, p.508) talks about how 'Berliners of Turkish descent have decided that rather than waiting for Germany to accept them as full citizens, they would carve out their own hyphenated identities'. This is because 'citizenship' is often associated with a Eurocentric theory of belonging which is state-bound, masculinist, singular and individualistic. The possibility of 'hyphenated' (ibid) or 'transnational' (Tyler 2013) identifications which are fluid is contrasted in such work with the singular, fixed and rigid identifications which sovereign citizenship maintains through 'its deployment as a technology of biopolitical governance in local regimes of mobility control' (ibid p.218). What is emphasised is the failure of the democratic promise of citizenship and, as such, the need to think about acts of citizenship in terms of how they move beyond ('act against') citizenship (Tyler and Marciniak 2013). 
I suggest that a danger of seeing belonging and identity invested in music and language as beyond or outside citizenship is that it reifies them and associates them with a problematic political space outside of (certain) struggles about inclusion and exclusion. It furthermore undermines the diversity of 'citizenship' broadly understood as contestations over rights. Indeed, a Foucauldian understanding of power as relational behoves us to recognise the ongoing relationship between politics and struggle and to understand "politics" as a struggle in terms of meaning and identity across inclusion(s) and exclusion(s). This is not to reduce all experiences of political identity and belonging to citizenship rather than beyond citizenship. It is to emphasise instead the need to think about hybridity across inclusion and exclusion within citizenship(Bosniak 2006); and precisely to refuse this citizenship/beyond citizenship binary.

The turn to music and language as explored above, although very much tied to more fluid and hybrid forms of linguistic and ethnic identity and belonging which shift and change given the vernacular nature of their grounding (and thus ungrounding) in street music and language, do not forego inclusionary and exclusionary logics. On the contrary, they produce/enact various lines of inclusion and exclusion through the different ways in which they link national, subnational and international, as well as linguistic and musical concepts, together. For example, rap and Verlan are linked to particular historical experiences, cultural characteristics and linguistic abilities as well as ethnic signifiers. It is by virtue of linking these together in particular ways that various forms of community are enabled as 'French rap' or 'Verlan' or 'Popular/global Rap'. As Ní Laoire et al note (2011 p.69), living in Ireland as predominantly young black men and women in a largely white culture, the turn to rap music and artists by intergenerational migrants 'make as well as reflect acceptable ways of being black in Irish society'. Lapassade (1996, p.52-65) elsewhere insists that 'noirceur' (blackness) is critical to rap, thus confirming the significant ways in which lines of inclusion and exclusion are drawn through rap despite its vernacular nature (see also Perry 2008).

This emphasis however placed on blackness is articulated to a large extent in ways which are not rigidly deterministic, unlike with sovereign statist citizenship. For example in the French banlieus, rap is also linked to identifications across the colour spectrum uniting many groups in their marginality - where being black is associated with being racialised - rather than the colour of one's skin (Durand 2002). The point is that identification with a community in rap and slang does not transcend or bypass ideas of nationality, statehood and inter-nationality nor of ethnicity and cultural specificity and the question of inclusion and exclusion. It does not provide a universal or a cosmopolitan envisaged space where identifications no longer matter or people have come to ignore these. Instead it interweaves various political identifications together in different ways at different 
times by trying not to ground them rigidly but nonetheless constantly re-grounding them (as ungrounded) in some ways rather than others.

Thinking about identification in vernacular music and language as struggles over inclusion and exclusion and thus as forms of citizenship, allows us to address questions, for example, about rap's highly deterritorialised nature which can celebrate the global at the expense of the local, as well as its highly consumerist nature which can result in prioritizing neo-liberalism at the expense of questions about structural inequalities. Another issue is rap's often problematic misogynistic nature, and the patriarchal hegemony which this perpetuates. These are all key aspects of the musical and linguistic space which marginalised intergenerational youth have carved out for an alternative fluid form of linguistic and ethnic identity and belonging which cannot be dismissed but nor should it be reduced simply to these factors. This emphasises the complexity of 'resistance' in this context. Engagement in vernacular music and language challenges mainstream national mono-lingualism and clear ethnic identification, and is thus linked to an understanding of the subversive. Yet, there are often many aspects which reinforce parts of the mainstream including its patriarchy and its narrow neo-liberal capitalist ideology; a problem pointed to within studies about contemporary 'subcultural' practices (Hebdige 1979; Huq 2001). My argument is thus that thinking about engagement with vernacular music and language as a form of citizenship helps us because it allows us to think about how these are realms of immanent relations and struggles which provide alternatives ideals of national community and identity at the same time as they remain a site of struggle over inclusions and exclusions which draw on aspects of these very same ideals.

\section{Conclusion}

The idea of citizenship as an act - as that seized (rather than bestowed) and transformed (rather than replicated) - emphasises the constantly in-formation, practice oriented 'incipient' (Isin and Nyers 2014a) nature of citizenship(s). Doing so it reminds us of the need to continually question and reassess what it is that we call citizenship - i.e. what we imagine as possible acts of resistance - as well as questioning who can be a citizen. With this in mind, this paper has turned to an undertheorised group within citizenship studies and also more generally within political studies - that of marginalised intergenerational migrant youth - to try to build on existing insights into the association between unfamiliarity and acts of citizenship, and to think about how unfamiliarity of acts challenges what we presume resistance to citizenship looks like. In the spirit of opening up our understandings of the various ways in which migrant communities resist citizenship from the 'margins', it considers the importance of recognising that marginalised intergenerational youths do 
so in different ways from marginalised migrant adults, although not simply reducing these actions to the question of youth.

This paper looked at the process itself through which some marginalised intergenerational migrants turn away from identifying or contesting their belonging and identity at the level of the nation-state towards vernacular music and language producing cross-lingusitic and ethnic expressions of self. This is what I am identifying as an act of citizenship: understood as an interruption by youth into existing socio-historical practices which currently define national language in mono or very narrow dualistic terms and designate ethnicity in a clear fashion. Such an act is interruptive in a way which is unusual (unfamiliar) as it is not a challenge to statehood, nationality or international society directly; it does not demonstrate the limits of these polities by questioning outright ('contesting' McNevin 2011) their boundaries. The latter gestures are the ones which we have come to recognise as ways of 'resisting' citizenship. The point is not that the categories associated with nationality (for example, Irish, French, American, African), statehood (e.g. France, Ireland, America, Nigeria), or an international polity (such as Europe, or Africa) longer apply or make sense here. Rather, the former (ideas of nationality) are inter-woven together without being grounded in statehood or an international polity - which is then resisted. Their only grounding is in vernacular music and language which at the same time results in their ungrounding, given the colloquial, non-standard nature of this vernacular music and language. 


\section{Bibliography}

Anthias, F. (2009) 'Translocational Belonging, Identity and Generation', Finnish Journal of Ethnicity and Migration, 4(1): 6-15

Ashutosh, I. (2013) 'Immigrant Protests in Toronto: Diaspora and Sri Lanka's civil War', Citizenship Studies, 17(2): 197-210

Bhabha, H. (1994) The Location of Culture (Abingdon: Routledge)

Bhabha, J. (2009) 'The "Mere Fortuity of Birth"? Children, Mothers, Borders, and the Meaning of Citizenship' in S. Benhabib and J. Resnik (eds), Migrations and Mobilities (NY: New York University Press): $187-227$

Blackledge, A. (2004) Constructions of Identity in Political Discourse in Multilingual Britain in A. Pavlenko, and A. Blackledge (eds) Negotiation of Identities in Multilingual Contexts (Clevedon: Cromwell Press): 68-92

Boehm, DA, Meredith, H. Coes, C, Rae-Epinoza, H and Reynolds RR (eds) (2011) Everyday Ruptures: Children, Youth and Migration in Global Perspectives (Nashville: Vanderbilt University Press)

Bosniak, L. (2006) The Citizen and the Alien (Princeton: Princeton University Press)

Butler, J. and Spivak, G.C. (2007) Who Sings the Nation State? (London: Seagull)

Cohen, E. (2005) 'Neither Seen nor Heard: Children's Citizenship in Contemporary Democracies', Citizenship Studies, 9(2): 221-240

Cutler, C and Royneland, U. (2015) 'Where the Fuck am I From? Hip-Hop Youth and the (Re)negotiation of Language and Identity in Norway and the US', in J. Nortier and BA Svendsen (eds) Language, Youth and Identity in the $21^{\text {st }}$ Century (Cambridge: CUP)

Darmody, M. Tyrrell, N. and Song, S. (eds) (2011) The Changing Faces of Ireland (Rotterdam: Sense Publishers)

Doran, M. (2004) 'Negotiating between Bourg and Racaille: Verlan as Youth Identity Practice in Suburban Paris' in (eds.) A. Pavlenko and A. Llackledge Negotiation of Identities in Multilingual Contexts (Clevedon: Cromwell Press Ltd)

Dowling, M. (1997) “"The Ireland that I would Have" De Valera and the Creation of and Irish National Image', Contemporary History, 2(5)

Durand, A.P. (2002) Black, Blanc, Beur: Rap Music and Hip-Hop Culture in the Francophone World (Scarecrow Press)

Drissel, D. (2009) 'Hip-Hop Hybridity for a Glocalized World”, The Global Studies Journal, 2(3): 121142

Fernandez-Kelly, P. and Konczal, L. (2007) 'Murdering the Alphabet: Identity and Entrepreneurship among second-generation Cubans, West Indians, and Central Americans', Ethnic and Racial Studies, 28(6): 1153-1181

Hebdige, D. (1979) Subculture: The Meaning of Style (New Accents)

Hoerder, D., Herbert, Y and Schmitt, I (eds) (2005) Negotiating Transcultural Lives (Toronto: University of Toronto Press)

Huq, R. (2001) 'Rap à la Française' in A Furlong and I Guidikova (eds) Transitions of Youth Citizenship in Europe (Council of Europe Publishing): 41-60

Isin, E and Neilson G.M. (eds) (2008) Acts of Citizenship (London: Zed)

Isin, E. and Nyers, P. (2014a) 'Globalizing Citizenship Studies' in E. Isin and P. Nyers (eds) Routledge Handbook of Global Citizenship Studies (Abingdon: Routledge)

Isin, E. and Nyers, P. (eds) (2014b) Routledge Handbook of Global Citizenship Studies (Abingdon: Routledge)

Kallio, K.P. (2012) 'Political Presence and the Politics of Noise', Space and Polity, 16(3): 287-302

Kallio, K.P. and Häkli, J. (2013) 'Children and Young People's Politics in Everyday Life', Space and Polity, 17(1): 1-16

Keyes, C.L. (2002) Rap Music and Street Consciousness (Chicago: University of Illinois Press) 
Lee, W.A. (2002) 'Passing as Korean-American' in D.T. Goldberg and A. Quayson (eds) Relocating Postcolonialism (Oxford: Blackwell)

Lentin, R. (2003) 'Pregnant Silence: (En)Gendering Ireland's Asylum Space', Patterns of Prejudice 37(3): 301-22

Lefkowitz, N. (1991) Talking Backwards Looking Forwards: The French Language Game Verlan (Tübingen: Gunter Narr)

Maira, S. (2005) 'The Intimate and the Imperial: South Asian Muslim Immigrant Youth after $9 / 11^{\prime}$ in S. Maira, and E Soep (eds) (2005) Youthscapes: The Popular, the National, the Global (Philadelphia: University of Pennsylvania Press)

Maira, S. (2008) 'We Ain't Missing' Palestinian Hip-Hop: A Transnational Youth Movement', The New Centennial Review, 8(2): 161-192

Maira, S and Soep, E. (eds) (2005) Youthscapes: The Popular, the National, the Global (Philadelphia: University of Pennsylvania Press)

Mancini, J. M. and Finlay, G., (2008) "Citizenship Matters"': Lessons from the Irish Citizenship Referendum', American Quarterly 60(3): 575-99.

McNevin, A., (2011) Contesting Citizenship: Irregular Migrants and New Frontiers of the Political (New York: Columbia University Press)

Morrison, I. (2008) 'Unintentional Acts of Citizenship (The Joke)' in E. Isin and B. Turner (eds) Acts of Citizenship (Zed Books): 221-223

Mushaben, J.M. (2008) 'Gender, Hip-hop and Pop-Islam: The Urban Identities of Muslim Youth in Germany', Citizenship Studies: 507-526

Neveu, C. (2014) 'Practicing Citizenship from the Ordinary to the Activist' in E. Isin and P. Nyers (eds) Routledge Handbook of Global Citizenship Studies (Abingdon: Routledge):86-95

Ní Laoire, C., Bushin, N., Carpena-Mendez, F. and White, A., (2009) Tell Me about Yourself (Cork: UCC) Ní Laoire, C., Carpena-Mendez, F., Tyrrell, N. and White, A. (2011) Childhood and Migration in Europe (Farnham: Ashgate)

Ní Mhurchú, A. (2014a) Ambiguous Citizenship in an Age of Global Migration (Edinburgh: Edinburgh University Press)

Ní Mhurchú, A. (2014b) Citizenship Beyond State Sovereignty in E. Isin and P. Nyers (eds) Routledge Handbook of Global Citizenship Studies (Abingdon: Routledge): 119-127

Nortier, J. and Dorleijn, M. (2013) 'Multi-Ethnolects' in P. Bakker and Y. Matras (eds) Contact Languages (Boston: De Gruyter Mouton): 229-272

Nortier, J and Svendsen, BA (eds) (2015) Language, Youth and Identity in the $21^{\text {st }}$ Century: Linguistic Practices Across Urban Spaces (Cambridge: Cambridge University Press)

Nyers, P (2008) 'No One is Illegal Between City and Nation' in E. Isin and B. Turner (eds) Acts of Citizenship (Zed Books)

Nyers, P and Rygiel, K. (2012) (eds) Citizenship, Migrant Activism and the Politics of Movement (Abingdon: Routledge)

Perry, M.D. (2008) 'Global Black Self-Fashionings: Hip Hop as Diasporic Space', Identities: Global Studies in Culture and Power, 15: 635-664

Portes, A. and Zhou, M. (1993) 'The New Second Generation: Segmented Assimilation and its Variants', Annals of the American Academy of Political and Social Science, 530: 74-96

Rosenthal, R. and Flacks, R. (2012) Playing for Change (London: Paradigm Publishers)

Safran, W. (1992) 'Language, Ideology and the State in French Nation-Building', History of European Ideas, 15: 793-800

Schmitt, I (2005) 'Germany Speaking? Rap and Kanak Attak and Dominant Discourses on Language' in D. Hoerder, Y. Herbert, and I Schmitt (eds) Negotiating Transcultural Lives (Toronto: University of Toronto Press)

Scott, J.C. (2014) 'Leaking Away and Other Forms of Resistance' in E. Tuck and KW Yang (eds) Youth Resistance Research and Theories of Change (Abingdon: Routledge) 
Sullivan, M (2001) 'African-American Music as Rebellion: From Slavesong to Hip-Hop', (Ithaca: Cornell University)

Tyler, I. (2013) 'Naked Protest: The Maternal Politics of Citizenship and Revolt', Citizenship Studies, 17(2): 211-226

Tyler, I and Marciniak, K. (2013) 'Immigrant Protest: An Introduction', Citizenship Studies, 17(2): 143156

Villard, F and Yan-Sayegh, P (2013) 'Redefining a (Mono)cultural Nation: Political Discourse against Multiculturalism in Contemporary France' in R. Taras (ed) Challenging Multiculturalism (Edinburgh: Edinburgh University Press)

Vinthagen, S. and Johansson (2013) "Everyday Resistance": Exploration of a Concept and Its Theories', Resistance Studies Magazine, 1: 1-46

Yau, N., (2007) 'Celtic Tiger, Hidden Dragon: Exploring Identity among Second Generation Chinese in Ireland', Translocations: Migration and Social Change 2(1): 48-69 